This is the accepted version of the paper published as Röder, A., Ward, M. and Frese, C. (2018)

"From labour migrant to stay-at-home mother? Childcare and return to work among migrant mothers from the EU Accession countries in Ireland", Work, Employment \& Society 32(5), 850-867. https://doi.org/10.1177/0950017017713953

\title{
From labour migrant to stay-at-home mother? Childcare and return to work among migrant mothers from the EU Accession countries in Ireland
}

Antje Röder, Philipps-Universität Marburg

Mark Ward, Trinity College Dublin

Carmen Frese, Independent Researcher

Previous research on the labour market integration of migrants from EU Accession countries has primarily viewed migrants as individual economic actors, despite their increasing role in family formation. In this contribution, mothers' return to work after birth is analysed using data from the Irish childhood prospective cohort study Growing Up in Ireland. Families from the Accession countries appear to have little access to nonparental childcare or the support of extended family, which is an important resource for their Irish peers. Fewer EU Accession mothers return to paid work at the end of maternity leave, and are more likely to juggle work and childcare without support. Structural reasons as well as preferences are considered as potential explanations to develop a better understanding of how migrant status impacts on work and childcare decisions.

Keywords: childcare; EU Accession; Ireland; labour market participation; migration; mothers

Corresponding author: Antje Röder, Institut für Soziologie, Philipps-Universität Marburg, 35032 Marburg, roeder@staff.uni-marburg.de

The labour market situation of migrants from the new EU member states in Ireland and elsewhere has been well documented, with research showing their over-representation in low wage jobs with irregular hours, fewer career development prospects, and little job security (see for example Barrett and McCarthy, 2007; Turner, 2010 for Ireland; Ciupijus, 2011; MacKenzie and Forde, 2009 for the UK). These migrants were largely young and single, and consequently have been viewed primarily as independent economic movers in public discourse and the academic literature, although there are some notable exceptions to this (Ryan et al., 2009; White, 2011). What seems to have remained relatively unnoticed, 
however, is that these formerly independent migrants have begun to form families in recent years. Births to non-Irish born mothers now make up about one quarter of all births in Ireland, and a large and growing proportion of these are from Accession States (Röder et al., 2014. Previous research shows that both general and maternal employment rates tend to be lower among non-native women, which is often attributed to human capital attributes and cultural preferences (Antecol, 2000). Furthermore, migrant families have been shown to rely disproportionately on informal childcare care (Bonizzoni, 2014), and also making less use of pre-school education (Sylva et al., 2007).

Despite this, little research has attempted to look at return to work and childcare together in the context of migration to evaluate the constraints and choices families face. The aim here is twofold: firstly, to develop a framework for explaining how migrant status interacts with choices made about return to work and childcare; and to examine whether this life-course transition reinforces existing disadvantages. Focusing on migrant families, however, also serves to highlight structural features of the current work and childcare regime more broadly that are frequently taken for granted. The Irish case is particularly interesting here, as the reliance on comparatively expensive private childcare provision on the one hand (McGinnity et al., 2013), and family - mostly grandparental - care on the other hand (McNally et al. 2014) provide a particularly challenging environment for those that may not have access to either. To do so, data from the nationally representative childhood cohort study Growing Up in Ireland (GUI) is used. This data is quite unique in having somewhat coincidentally captured the trend of family formation among recent migrants, thus providing an opportunity to study this important topic with a large, representative sample. Low rates of return to work and use of non-parental childcare are found among mothers from Accession States after the birth of a child. We argue that structural disadvantages of migrants within the labour market and difficulty in accessing childcare create strong barriers to mothers return to work, which has a particularly negative effect when taken together with unfavourable or ambivalent attitudes towards non-parental care. 


\section{Mothers' labour market participation: between "choices" and "constraints"}

Women's employment has risen substantially across many societies, and attitudes have largely become much more supportive of women's paid work. Yet, when it comes to the division of housework and childcare, little progress appears to have been made (England, 2010). In particular when the first child is born, there is frequently a "re-traditionalisation" of roles (Grunow and Evertsson, 2016), with women taking on the main childcare and housework responsibilities, and withdrawing, at least temporarily, from the labour market, and then frequently returning only to part-time work. Questions about the choices and constraints families face in this matter are the subject of much, at times heated, public and academic debate. The economic literature suggests that the decision to work depends primarily on the opportunity cost of foregone income versus the cost of working in terms of less time being available for care and housework (Becker, 1981). The human capital mothers possess consequently determines the benefit of work, not only in terms of income but also in terms of longer term career prospects and satisfaction from work (Konietzka and Keryenfeld, 2010). Childcare costs, on the other hand, are outside the influence of the human capital of mothers, and the main way to reduce this cost is by the using informal arrangements, particularly support by family members. Unsurprisingly then, research shows that the higher skilled have greater recourse to formal childcare, while the lower skilled either use no childcare at all, or make informal arrangements (Debacker, 2008).

Economic costs and benefits, however, cannot explain all of the variation between families, and gendered norms and values have to be taken into account (Vlasblom and Schippers 2006). Hakim (2000) in her preference theory even argues that women in countries such as the UK can now realise their work-family preferences without major constraints, and that individual preferences are the main explanation for their heterogeneous labour market participation. This approach has been criticised for overemphasising the role of personal choice while downplaying structural constraints that continue to have a major impact on outcomes (see for example Duncan et al., 2003). In line with McRae (2003) we argue here that constraints are both structural and normative; the former relate to job availability, the cost of childcare and social class, while the latter include women's (gendered) identities as well as attitudes and gender relations within families. It is therefore useful to consider these explanations together as they interact to 
determine which options are available, and which are considered preferable. The decision to return to work will firstly depend on available employment opportunities and childcare options, which are primarily shaped by the socio-economic position of the family and the support network they can draw on. For example, if no relatives are available to help with childcare, then a return to work will typically only be possible with the use of paid childcare, which in turn is only feasible if the family can afford it. Available options are then subjected to a cost-benefit analysis, which, importantly, includes not only economic but also moral and emotional considerations about the perceived needs of children and parents. Care provided by relatives, for example, is often preferred not only because it is more affordable, but because it is seen by many parents as providing emotional benefits (Wheelock and Jones, 2002). Hence, preferences play a role in this decision making, but include a much wider set than career versus family orientations (Hakim, 2000). Rather than understanding preferences as entirely stable, pre-existing attitudes on how to combine work and family, we consider them as factors that influence the evaluation of what is the best option under given circumstances, which may also be adapted to realities to resolve role conflicts (Kroska and Elman, 2009). Economic factors go beyond immediate income, and include considerations of the impact of a career break in the longer term, the financial security provided by a second income, or the perceived level of income required to provide adequately for a family. Non-economic reasons include the importance of an identity and outlet outside of the family, the (perceived) emotional needs of children and parents, and, linked to this, beliefs about the benefits and disadvantages of non-parental childcare. These are all shaped by socially negotiated views about appropriate parenting, which in turn differ between social classes (McRae, 2003) and are strongly gendered with a moral expectation that mothers in particular put their children's needs first (Duncan et al. 2003).

This is not to suggest that decisions are necessarily taken in this order, or that parents know and consider all theoretically available options. Indeed, some options may never be contemplated if they are not known, or if personal beliefs are very strong. Yet such a model can help structure a complicated decision-making process, and also provides a framework with which to evaluate how migrant status intersects with this process. Before turning to this, the Irish context is considered to show why Accession State migrants in Ireland provide a particularly relevant case for developing and examining this argument. 


\section{Employment and childcare in Ireland}

Individual choices families make - be they due to preferences or structural constraints - do not happen in a vacuum, and are moderated by the broader policy and economic environment (Janus, 2013). Policy choices made by governments are in turn informed by the gender contract in a given society. Historically, Ireland had particularly low rates of female labour market participation, which changed quite rapidly in recent decades, with greater proportions of women generally, and women with children in particular, being active in the labour market (O'Connell and Russell, 2007; Russell et al., 2009). About one-third of overall female employment is part-time, though this is not a guaranteed right for parents (Russell and McGinnity, 2011). Furthermore, part-time employment tends to be in lower paid sectors and occupations (O'Connell and Russell 2007), similar to the UK (Himmelweit and Sigala, 2004). These changes are also reflected in attitudes towards maternal employment that have become much more supportive in recent decades (O'Sullivan, 2012). Yet, relatively few people support a dual earner model when children are young, with almost half of 25 to 35 year olds being in favour of women working part-time, and over one quarter favouring a stay-at-home mother (ISSP, 2014; see Appendix 1).

While there has been some investment in childcare provision in recent years in Ireland, the main responsibility continues to lie within the private sector, which continues to have negative repercussions for affordability (Hayes and Bradley, 2006). The relatively recent establishment of a free preschool year (ECCE) has only limited impact on this, as it only covers part-time care for one year before children enter school. Unlike in the UK, there are no tax credits for childcare, although there are some community childcare schemes that provide a very limited number of subsidised places. Current maternity leave provisions allow for 26 weeks of paid and 16 week of unpaid leave. In a context of high cost of childcare and lack of fiscal supports it is unsurprising that several studies show that there is strong dependence on relative childcare, particularly provided by grandparents (Hayes and Bradley, 2006; McNally et al., 2014). Overall, it seems that policies around childcare (and eldercare) have not kept up with recent developments (Doyle and Timonen, 2010), creating a challenging environment, particularly for migrant families. 


\section{Dual disadvantage?}

A vast literature documents migrant disadvantage in the labour market and links this to both individual factors, such as the need to acquire location specific human capital, and contextual or institutional factors, such as lack of recognition of qualifications, employer discrimination or segmented labour markets (Kogan, 2010). Similarly, there is ample evidence that women continue to experience penalties in the labour market, which can be traced back to occupational segregation and their continued role as main carers in the family (England, 2010). Female migration has long been seen mainly through the lens of family migration, with women being "tied" or "secondary" movers, a role which intensifies their dependency (Ackers, 2004). However, women are increasingly recognised as economic migrants in their own right, and it is argued that they experience "double disadvantage" due to their migrant status and their status as women in gendered labour markets (Raijman and Semyonov, 1997). The cohort of migrants studied here had their first child after migration and after having already participated in the Irish labour market, and as such cannot be considered as typical "tied" movers. Yet, family formation reinforces traditional family patterns, which, as we will illustrate, is intensified in the context of migration.

Several qualitative studies describe the strategies used by migrant families to balance work and care. Relatives are frequently relied on where possible, and grandparents are in some cases brought to live with the family. In the absence of such support, care is juggled within the nuclear family, delegated transnationally to family members in the origin country, or locally to informal childminders found via ethnic networks (Bonizzoni, 2014; Dyer et al., 2011). Irregular working hours among lower paid (migrant) workers further contribute to the difficulty of combining work and family (Evans et al., 2005). In a qualitative study of migrant care workers in Ireland Doyle and Timonen (2010) found that migrant families relied almost exclusively on informal childcare arrangements, such as bringing their own parent(s) to Ireland for extended stays or exchanging childcare services with other migrants, mirroring the relatively high reliance on informal and family care in Ireland observed more generally among the lower skilled (McGinnity et al., 2013; McNally et al., 2014). Furthermore, quantitative studies in other countries confirm that fewer migrant and ethnic minority children are enrolled in pre-school education and are more frequently found in informal childcare arrangements (see for example Sylva et al., 2007). 
Applying the framework developed above, it becomes clear that migrants experience greatly constrained choices: they will less often be in a position to afford paid childcare, and less often have relatives nearby who can provide care. The financial benefit of working after paying for childcare may be low due to relatively low wages, and career opportunities are unlikely to act as a major incentive given the relatively poor career development opportunities in the jobs typically occupied by this cohort of migrants (Barret and McCarthy, 2007). The empirical expectation is therefore that immigrant parents rarely use formal, nonrelative childcare, less frequently use relative childcare than their Irish peers, and that mothers therefore frequently stay at home. Parents who require a second income will more often juggle work and childcare without additional childcare support. These patterns should be primarily explained by the socio-economic status of families and the absence of family nearby unless other, non-economic factors, play a role, which is examined in the next section.

\section{Different preferences?}

Different gender roles and views of appropriate childcare may tip the balance more easily towards migrant mothers staying at home compared to native-born mothers even when families are in a similar economic position. Gender role attitudes of migrants continue to be influenced by the prevalent attitudes in the origin societies (Kavli, 2015; Röder and Mühlau, 2014), which is an important explanation for lower female labour force participation (Antecol, 2000). In this context it is worthwhile to look at the situation in the origin countries to better understand how this might influence parents' choices after migration. A double standard continues to exist in many Eastern and Central European countries, where on the one hand women participate at quite a high level in the labour market, but on the other hand social norms continue to be more supportive of traditional gender roles shaped by patriarchal systems (Steiber and Haas, 2009; White 2011). This is argued to be a legacy of communist times, during which women were encouraged by the state to participate widely in the labour market, but remained the main carers and homemakers. During the transition from communism the previous state imposed system was rejected by many in favour of the 
male breadwinner model, yet the economic realities of the transition period continued to frequently require two wage earners (Crompton et al., 2005; Pollert, 2003).

Examining data from the International Social Survey Programme (ISSP, 2014), we see that among 25 to 35 year olds (i.e. the main age group in the sample) in Ireland there is a strong preference for mothers of young children working part-time, while attitudes in all origin countries except Slovenia support a stay-at-home mother most frequently, although this is less pronounced in Poland. Slovenia is also the country with by far the most supportive attitudes towards dual earner parents, and this is reflected in very high maternal employment rates. Across all other origin countries, maternal employment is similar or higher than in Ireland, but not when children are very young, which in part reflects different parental leave systems (Appendix 1).

How might this impact on migrants' labour force participation in Ireland? While migrant parents are quite diverse in their preferences, the greater preference for mothers staying at home in the main origin countries represented in the sample should lead to lower return to work after birth overall, even when structural aspects of the living situation in Ireland are taken into account. Additionally, there is evidence that migrants frequently do not trust childcare in the host country or perceive it as not being culturally inclusive (Cooke, 2007), which makes this option less attractive. Given the expected small economic benefit of working when childcare costs are taken into account, even mothers with ambivalent attitudes may opt out of the labour market. Including attitudinal measures directly to test this is problematic, as it is well known that attitudes are frequently modified as a result of particular choices made (Himmelweit and Sigala, 2004; Steiber and Haas, 2009). Additionally, there are some limitations in how attitudes are measured in the dataset that are further discussed below. We nevertheless examine whether there is a mismatch between the hours mothers work, and the hours they would like to work as a proxy for different preferences, and examine, if cautiously, the degree to which preferences differ between Irish and migrant mothers. 


\section{Data, variables and methods}

This study consists of an analysis of data from the families of nine-month-old infants collected as part of the first wave of Growing Up in Ireland (GUI). The Child Benefit Register provided the sampling frame, with a final sample of 11,134 children and their families (response rate 64 per cent), representing 27 per cent of all children born in Ireland between December $1^{\text {st }} 2007$ and June $30^{\text {th }} 2008$ (Quail et al., 2011). Here we limit the analysis to first time mothers (singleton birth) only to enable more parsimonious comparisons. Given the interest in migrants from Accession States, mothers born in one of the countries that joined the EU in 2004 were included as well as Irish born mothers as the comparison group. Sample proportions reflect migration patterns to Ireland after 2004, with the largest group being Polish nationals followed by Lithuanians, and Latvians. This provided an effective sample size of 3,835 of which 636 are from EU Accession countries. First time mothers from Accession states are on average younger, have similar educational levels as Irish mothers, and are less frequently single parents (see Appendix 2). It should also be noted that almost all of the migrant mothers had a partner from the same country, who was also more frequently out of work, reflecting the higher unemployment among this cohort during the study period (Krings, 2010).

\section{Variables}

The main dependent variable for analysis is a work-childcare typology. This typology follows the approach advanced by Debacker (2008) whereby mothers' employment status and childcare arrangement are considered in conjunction, thereby acknowledging that the decisions mothers make about their labour market participation is shaped, at least in part, by the childcare options available to them. Participants were categorised into one of five groups: full-time employment with non-relative childcare; full-time employment with relative childcare; part-time employment with non-relative childcare; part-time employment with relative childcare; no paid employment or use of non-parental childcare; full- or part-time work with no use of non-parental childcare. Mothers were classified as 
part-time if they reported working less than 30 hours per week ${ }^{1}$. Non-relative childcare arrangements referred to care provided by non-family members, including: an au pair or nanny; registered or unregistered child minder; friend or neighbour; any form of centrebased care which includes crèche, Montessori, and nursery. Relative childcare arrangements included care provided by members of the parents' extended family, frequently grandparents.

Employed mothers were asked about their preferred hours of work if they could choose freely. Again, working less than 30 hours was considered part-time and this was compared to the actual hours worked. They were also asked what the main reason for their return to work was. Options given were: financial and job related benefits (joined into one category), maintaining a career, and needing an outlet outside the home. Mothers who had not returned to worked were asked why, and could rank up to three reasons in order of importance. The highest ranked reasons were combined to reflect choice versus (perceived) constraints: choice/preference to look after children; lack of (suitable) job; unsuitable/expensive childcare; others (caring for elderly, would lose benefits).

To capture human capital, mother's education is used. While household income variables were available at nine months, these are problematic given that at this time point they are in substantial part the result of work choices. Education therefore better captures the earnings capabilities of the mother independently of the work/childcare choice made by the family. It is coded as lower secondary or less, leaving certificate, non-degree postsecondary and degree or higher. As migrants require time to convert their human capital in the host country, we control for length of residence in addition to migrant status. Most of the mothers had arrived within five years before data collection with a smaller number in the country for longer, both captured in a binary variable. Additionally, migrant specific human capital includes language competence, which mothers self-assessed based on their ability to read or fill out forms in English.

\footnotetext{
${ }^{1}$ This is a common cut-off point for part-time versus full-time work, although this hides the great diversity amongst part-time workers, which can range from very few to almost full-time equivalent hours. Equally, parents may work more than one job for greater flexibility. Several different cut-off points for part-time hours were tested and results changed little, so that the general pattern is robust, although it is acknowledged that the complexity of part-time work choices cannot be reflected here.
} 
To capture the broader socio-economic position of the family, social class is used. Household social class was measured using the Irish Central Statistics Office schema and coded according to the International Standard Classification of occupations 1988 (ISCO88). Social class was arrived at using a dominance procedure so that in two-parent households where both were economically active the household social class was assigned as the higher of the two. We used a four category classification: professional and managerial; other nonmanual and skilled-manual; semi-skilled and unskilled manual; others unknown or never worked. Family living nearby was self-reported by mothers as either yes or no. Control variables in the models are mother's age and partner's employment status; the latter is combined with whether there is a partner in the household at all, so that the categories are no partner; partner not working; partner working; and missing employment information. Modelling

After presenting the main work pathways before and after birth, multinomial logistic regression models are estimated with the dependent variable being the different work/childcare combinations (reference category: mother not working and not using childcare). Analyses exclude mothers who did not work before birth from further analyses. It should be noted, however, that the vast majority of those that did not work before birth remain outside the labour market. As mediation effects are of interest, that is, whether accounting for differences such as occupation or family characteristics between migrant and Irish mothers can explain the gap in work and childcare outcomes, coefficients rather than odds ratios are reported.

$\underline{\text { Return to work and childcare: A comparison of Irish and migrant mothers }}$

A large majority of women worked before giving birth to their first child (see Appendix 1): 80.7 per cent of Irish women and 71.7 per cent of Accession state women had a full-time job, with 10.9 and 13.7 per cent respectively working part-time. More migrant mothers were out of work (14.2 versus 8.4 per cent), reflecting the higher unemployment within this cohort. Figure 1 shows the pathways from pre-birth to post-maternity leave labour force participation, excluding those that did not work before birth. Several major differences can be seen: while similar proportions in both groups reduced from full-time to part-time or 
maintained part-time work, many more migrant mothers did not return to work at all, leaving a much smaller proportion in full-time work (25.3 compared to 38.9 percent or Irish mothers) $)^{2}$.

Figure 1 about here

As argued above, work and childcare decisions are likely to be linked, and some of the explanation for differential return to work may lie in access and use of different types of childcare. Examining childcare patterns (see Appendix 2), we find that just over 10 per cent of migrant families used non-relative childcare (1.9 per cent centre-based childcare and 8.2 per cent non-relative childminders) compared to almost 30 per cent (15.5 and 14.2 per cent respectively) among Irish families. Migrant families were about half as likely to use relative childcare (12.8 compared to 24.5 percent), with a further difference being that in migrant families this care was typically provided in the child's home, whereas among Irish families it was more frequently in the relative's home. Over three quarters (76.9 per cent) of migrant families did not use any non-parental childcare at all, compared to less than half ( 45.5 per cent) of Irish families. Figure 2 illustrates the extent to which both groups combine work and childcare. In Irish families, maternal labour force participation tended to be facilitated by some form of non-parental childcare. Only 7.6 per cent work without any use of nonparental childcare, compared to almost one quarter of migrant mothers.

Figure 2 about here

\footnotetext{
${ }^{2}$ Analyses of the second wave of data when children were 3 years of age show that these patterns are relatively persistent also over a longer timeframe (see also Appendix 3).
} 
To test the extent to which the different socio-economic position of families may be behind these differences, multinomial logistic regression models are estimated with the reference category being mother not working and not using childcare. Model 1 (Table 1) presents findings when only looking at the difference between migrant and Irish mothers, and confirms the patterns described above. Model 2 adds length of residence and language ability for migrants. Having been in Ireland longer and having better English language skills had a positive effect on all work and childcare combinations, except for a negative effect of length of residence on working while not using childcare. Coefficients for length of residence remained well below conventional significance levels, which may be due to the low case number of longer staying migrants in this cohort. Language ability in some cases (almost) reached significance despite the low case numbers of those indicating poorer English competency.

Model 3 controls for mother's educational level, family social class, mother's age, partner's situation, and whether family lives nearby. Maternal education, as would be expected, had a strong effect on childcare use and work. This was most clear for full-time work and non-relative childcare, which was much more likely to be a combination selected by highly educated women. Higher social class was associated with returning to full-time work and using non-relative and, to a lesser extent, relative childcare. Young mothers used non-relative childcare less often, while older mothers less often used relative childcare. Single mothers were more likely than partnered mothers to stay at home, or to juggle work without childcare. Mothers whose partner was not working more often worked part-time rather than stay at home. Having family nearby had a positive effect across all combinations, but only significant and, unsurprisingly, very substantial in size for care provided by relatives.

Table 1 about here

Did these factors also reduce the gap between migrant and native mothers? The inclusion of socio-economic status reduced the gap in terms of accessing non-relative childcare, 
particularly for mothers who worked full-time and to a lesser extent for those that worked part-time, which can be seen in the reduced coefficients for EU Accession in Model 3 compared to Model $2^{3}$. It should be noted that the main driver behind closing this gap was social class status rather than maternal education, reflecting the fact that migrants' occupational attainment does not mirror their educational levels. For full- or part-time work combined with relative childcare the gap increased before we include whether family lives nearby (not shown here; coefficients -0.729 (S.E. 0.201) and -1.488 (S.E. 0.296) respectively). Given their socio-economic profile and age, migrants should actually be expected to use relative childcare more often. Once presence of family was included, effects reduced but remain strongly significant. Working without using non-parental childcare remained much more likely for migrant mothers, although the gap closed slightly.

\section{Preferred hours and reasons for (not) returning to work}

Socio-economic status and the lack of family living nearby could not explain differences entirely. This could reflect different preferences among families, which was examined in the next step. Firstly, among those mothers who worked, we compared their actual work hours with their preferred hours. Out of those mothers working full-time, 42.3 per cent or Irish and 69.8 per cent of migrant mothers want to work full-time, while 57.7 and 30.2 per cent respectively would prefer to work part-time instead. The vast majority of Irish mothers working part -time wanted to do so (90.7 per cent). Migrant mothers indicated in 63.1 per cent of cases this reflected their preference, while the remaining 36.9 per cent would like to work full-time hours. This indicates that migrant mothers working full-time more often than Irish mothers appeared do so by choice, while part-time work seemed to be more frequently involuntary.

When examining reasons why mothers returned to work, 79.6 per cent of migrant mothers said that this was mainly for financial reasons compared to 67.8 per cent of Irish mothers. Maintaining a career (including self-employment) was cited by only 7.5 per cent of migrant mothers compared to 21.2 per cent of Irish mothers. Needing an outlet was quite similar in importance (11.4 versus 9.6 per cent). When mothers who did not return to work

\footnotetext{
${ }^{3}$ Results are robust when mother's occupational status before birth or household income is used.
} 
were asked why they did not, the vast majority of both migrant and Irish mothers (71.0/67.9 per cent) said that the most important reason was that this was their preference. 15.8 versus 18.9 per cent could not find a suitable job, and 11.1 versus 6.8 per cent could not find suitable childcare (the remainder cited other reasons).

\section{Discussion and conclusion}

Our findings show that there are large differences in the childcare and work patterns after having a child between Irish and migrant families from the EU Accession countries. More than three quarters of migrant families do not use any form of non-parental childcare compared to less than half of Irish families. This is partly because they less frequently have relative care available, which is a popular option, especially among lower income Irish families. When relatives provide care in migrant families, this tends to take place in the child's home, indicating that relatives may be brought to Ireland for this purpose (Doyle and Timonen, 2010). Even more noticeable is the large difference in accessing care provided by non-relatives, which is very rarely used in migrant families. This creates a situation whereby fewer migrant mothers work after the birth of their first child, and if they do, this takes place half of the time without access to non-parental childcare. This confirms in a large representative sample findings from previous qualitative studies (Bonizzoni, 2014; Dyer et al., 2011) that show that migrants adopt this strategy. These studies suggest that this happens especially when parents have irregular working hours around which they can divide their family responsibilities without having to pay for childcare.

Given the timing of this cohort study we should consider the impact of the severe economic recession in Ireland before interpreting the findings further. The higher unemployment rate of both the mothers and fathers in the migrant sub-sample already show that they were more severely affected by the recession (Krings, 2010). While jobs are in principle guaranteed for the duration of maternity leave, this may be more difficult to enforce in less secure types of contracts. Yet, we only found a very small difference in terms of migrant mothers indicating an inability to find a job, although there is some evidence of involuntary part-time work. The data do not allow us to differentiate whether this is due to lack of hours available from the employer side, or the inability to work more due to family 
commitments or other circumstances. While the recession may have intensified some of the patterns, it does not seem to be the main explanatory factor for what is observed here.

When differences in human capital fail to fully explain heterogeneous labour force participation, research in this area often attributes unexplained variance to different cultural influences. This assumes that all other relevant factors are adequately captured, which is difficult to achieve despite the wealth of information available in the Growing Up in Ireland dataset. More importantly however, it does not further our understanding of the complicated interaction between structural constraints and preferences in the context of migration that were developed in the framework above that we return to now to evaluate our findings. There is support for the hypothesis that available work and childcare options for families are determined to a large extent by socio-economic position as well as the available support network. It is also clear that migrants are at a substantial disadvantage with regards to both of these. When relatives are not available, migrant parents effectively seem to select between being a stay-at-home mother or working without additional childcare support. Non-relative childcare is largely avoided, which is only partly explained by socio-economic factors. Therefore cost cannot be the only reason, and more negative views of non-parental care, lack of knowledge and potentially even mistrust in the host country's childcare system (Cooke, 2007) are likely to contribute.

What then differentiates between stay-at-home mothers and "jugglers"? It is not simply that some have to work and others can afford not to, since both outcomes exist in substantial proportions across social classes. Might this be down to strong work orientations among those that do return to work? Examining the reasons given by mothers leads to a more differentiated view: migrant mothers more often than their Irish peers say they are happy in full-time work or would indeed like to work more hours than they currently do. At the same time though, they indicate a greater importance of financial reasons for returning to work rather than career or self-fulfilment, which also reflects the poorer career development opportunities of the jobs they typically hold (Barrett and McCarthy, 2007). This suggest that there is high motivation to work among those that do, which does not surprise given that the option of juggling work without additional childcare support is challenging and requires determination. However, this does not appear to reflect work orientations understood as lifestyle preferences (Hakim, 2000), but seems to be largely born 
out of perceived financial necessity. This mirrors the ambivalent position of this cohort of migrants: on the one hand, their migration was motivated by economic factors and the aim to improve economically; on the other hand they come from societies where a mother staying at home with the children continues to be the preferred, if often unrealistic, option. If they prioritise economic improvement, the expense of childcare would leave little additional benefit of a second income for the family. The option of sharing childcare between parents consequently makes financial sense and avoids leaving the child in the care of non-family members, but will of course only be open to those with relatively flexible schedules and partners who support this. Further research may investigate if this actually serves to involve fathers more strongly and potentially even challenge traditional gender roles in migrant families.

Families who prioritise the importance of a mother staying at home will have to make some financial sacrifices, but overall the situation of the family will in many cases still be better than that in the origin country, especially when taking into account universal child benefit and supports for low income families. The high proportion of mothers who indicate that staying at home is their choice would seem to support the idea that this model reflects preferences, although we have to be careful given that attitudes are often adjusted to a given situation (Kroska and Elman, 2009). While for some families their circumstances in Ireland allow them to enact their preferences better than they would have in the origin country, there will be many for whom this is simply the only practicable model given their socio-economic position, as outlined above, and if they are unable or unwilling to "juggle".

This all shows that preferences intersect with structural constraints to produce the outcomes we have observed. Some of these constraints are specific to migrants and are therefore likely to occur in other settings. This applies in particular to the absence of family, although families often go to remarkable lengths to support each other transnationally (Ryan, 2009). Lower socio-economic status, a desire to improve socio-economically and different preferences about childcare are equally not unique to this migrant cohort. Nevertheless, some of the effects are intensified by the institutional setting in Ireland, which seems to be remarkably efficient in turning former labour migrants into stay-at-home mothers. Even more problematic perhaps is that there is little support available to those who want or need to work. This reflects a more general structural issue of the Irish system, 
where lower income groups are effectively excluded from accessing non-relative childcare due to cost (McGinnity et al., 2013), which has particularly strong consequences when relatives are not on hand to counter-balance this. The observed outcomes are therefore unsurprising given that there is little to incentivise mothers to return to work, especially when this is coupled with at best ambivalent attitudes about maternal employment. The situation in the UK is unlikely to be much different since migrants from the Accession states hold similar occupational positions, and since less affluent parents also rely strongly on informal arrangements and grandparental care (Crompton and Lyonette, 2010), as private care is very expensive despite certain tax credits and the provision of some hours of free childcare. This situation raises questions about the consequences this will have for these mothers, but also the labour market and welfare systems in the longer term. While this cohort of female migrants did not arrive as traditional "tied movers", gender inequalities are nevertheless exacerbated as a result of family formation. It is well established that long breaks after having children are penalised significantly in the labour market (Evertsson and Duvander, 2011), and the already disadvantaged position of these migrants in the labour market could be further reinforced.

\section{Acknowledgements}

The authors would like to acknowledge research funding received from the Irish Research Council Starter Grant for the "New Irish Families" project, which made the work leading to this article possible. 


\section{References}

Ackers L (2004) Citizenship, migration and the valuation of care in the European Union. Journal of Ethnic and Migration Studies 30(2): 373-396.

Antecol H (2000) An examination of cross-country differences in the gender gap in labor force participation rates. Labor Economics 7(4): 409-426.

Barrett A, McCarthy $Y$ (2007) Immigrants in a booming economy: Analysing their earnings and welfare dependence. Labour 21(4): 789-808.

Becker GS (1981) A Treatise on the Family. Cambridge, MA: Harvard University Press.

Bonizzoni P (2014) Immigrant working mothers reconciling work and childcare: the experience of Latin American and Eastern European women in Milan. Social Politics 21(2): 194-217.

Ciupijus Z (2011) Mobile central eastern Europeans in Britain: successful European Union citizens and disadvantaged labour migrants? Work, Employment and Society 25(3): 540-550.

Cooke FL (2007) 'Husband's career first': renegotiating career and family commitment among migrant Chinese academic couples in Britain. Work, Employment and Society 21(1): 47-65.

Crompton R, Brockmann M, and Lyonette C (2005) Attitudes, women's employment and the domestic division of labour: a cross-national analysis in two waves. Work, Employment and Society 19(2): 213-33.

Crompton R, Lyonette C (2010) Family, class and gender 'strategies' in mothers' employment and childcare. In: Scott C, Crompton, R, and Lyonette C (eds) Gender Inequalities in the $21^{\text {st }}$ Century. Cheltenham: Edward Elgar Publishing, 174-192.

Debacker M (2008) Care strategies among high- and low-skilled mothers: a world of difference? Work, Employment and Society 22(3): 527-545.

Doyle M, Timonen V (2010) Obligations, ambitions, calculations: Migrant care workers' negotiation of work, career, and family responsibilities. Social Politics 17(1): 29-52.

Duncan S, Edwards R Reynolds T, and Alldred P (2003) Motherhood, paid work and partnership: Values and theories. Work, Employment and Society 17(2): 309-330.

Dyer S, McDowell L, and Batnitzky A (2011) Migrant work, precarious work-life balance: What the experiences of migrant workers in the service sector in Greater London tell us about the adult worker model. Gender, Place and Culture 18(5): 685-700.

England P (2010) The gender revolution uneven and stalled. Gender and Society 24(2): 149166. 
Evans Y, Herbert J, Datta K, May J, Mcllwaine C, and Wills J (2005) Making the City Work: Low paid employment in London. London: Department of Geography Queen Mary, University of London.

Evertsson M, Duvander A (2011) Parental leave, possibility or trap? Does family leave length effect Swedish women's labour market opportunities? European Sociological Review 27(4): 435-450.

Grunow D, Evertsson M (2016) Couples' Transitions to Parenthood: Analyzing Gender and Work in Europe. Cheltenham: Edward Elgar Publishing.

Hakim C (2000) Work-Lifestyle Choices in the $21^{\text {st }}$ Century: Preference Theory. Oxford: Oxford University Press.

Hayes N, Bradley S (2006) The childcare question. In: Fanning B, Rush M (eds) Care and Social Change in the Irish Welfare Economy. Dublin: UCD Press, 163-178.

Himmelweit A, Sigala M (2004) Choice and the relationship between identities and behaviour for mothers with pre-school children: some implications for policy from a UK study. Journal of Social Policy 33(3): 455-478.

ISSP (2014) International Social Survey Programme: Family and Changing Gender Roles IV ISSP 2012. Cologne: GESIS Data Archive (ZA5900 Data file Version 2.0.0).

Janus AL (2013) The gap between mothers' work-family orientations and employment trajectories in 18 OECD countries. European Sociological Review 29(4): 752-766.

Kavli H (2015) Adapting to the dual earner family norm? The case of immigrants and immigrant descendants in Norway. Journal of Ethnic and Migration Studies 41(5): 835-856.

Kogan I (2010) Working through Barriers: Host country institutions and immigrant labour market performance in Europe. Dordrecht: Springer.

Konietzka D, Keyenfeld M (2010) The growing educational divide in mothers' employment: An investigation based on the German micro-censuses 1976-2004. Work, Employment \& Society 24(2): 260-278.

Krings T (2010) Ireland. In: Migration and the Economic Crisis: Implications for Policy in the European Union. Geneva: International Organization for Migration, 103-119.

Kroska A, Elman C (2009) Change in attitudes about employed mothers: exposure, interests, and gender ideology discrepancies. Social Science Research 38(2): 366-382.

McGinnity F, Murray A, and McNally S (2013) Growing Up in Ireland: Mothers' Return to Work and Childcare Choices for Infants in Ireland. Dublin: ESRI. 
MacKenzie R, Forde C (2009) The rhetoric of the 'good worker' versus the realities of employers' use and the experiences of migrant workers. Work, Employment and Society 23(1): 142-159.

McNally S, Share M, and Murray A (2014) Prevalence and predictors of grandparent childcare in Ireland: Findings from a nationally representative sample of infants and their families. Child Care in Practice 20(2): 182-193.

McRae S (2003) Constraints and choices in mothers' employment careers: a consideration of Hakim's Preference Theory. British Journal of Sociology 54(3): 317-338.

OECD (2016) OECD Family Database: Maternal employment rate by family status. Paris: OECD.

O'Connell P, Russell H (2007) Employment and the Quality of Work. In: Fahey T, Russell H and Whelan CT (eds) Best of Times. The Social Impact of the Celtic Tiger. Dublin: Institute of Public Administration, 43-66.

O'Sullivan S (2012) All changed, changed utterly? Gender role attitudes and the feminization of the Irish labour force. Women's Studies International Forum 35(4): 223-232.

Pollert A (2003) Women, work and equal opportunities in post-communist transition. Work Employment \& Society 17(2): 331-357.

Quail A, Williams J, McCrory C, Murray A, and Thornton M (2011) Sample design and response in wave 1 of the infant cohort (at nine months) of Growing Up in Ireland. Dublin: Department of Children and Youth Affairs.

Raijman R, Semyonov M (1997) Gender, ethnicity and immigration- double disadvantage and triple disadvantage among recent immigrant women in the Israeli labor market. Gender \& Society 11(1): 108-125.

Röder A, Ward M, Frese C, and Sánchez E (2014) New Irish Families: A Profile of Second Generation Children and their Families. Dublin: Trinity College Dublin/Migration and Employment Research Centre.

Röder A, Mühlau P (2014) Are they acculturating? Europe's immigrants and gender egalitarianism. Social Forces 92(3): 899-928.

Russell H, McGinnity F, Callan T, and Keane C (2009). A Woman's Place: Female Participation in the Irish Labour Market. Dublin: The Equality Authority/ESRI.

Russell H, McGinnity F (2011) Workplace Equality in the Recession? The Incidence and Impact of Equality Policies and Flexible Working. Dublin: The Equality Authority/ESRI.

Ryan L, Sales R, Tilki M, and Siara B (2009) Family strategies and transnational migration: Recent Polish migrants in London. Journal of Ethnic and Migration Studies 35(1): 61-77. 
Steiber N, Haas B (2009) Ideals or compromises? The attitude-behaviour relationship in mothers' employment. Socio-Economic Review 7(4): 639-668.

Sylva K, Stein A, Leach P, Barnes J, and Malberg LE (2007) Family and child factors related to the use of non-maternal infant care: an English study. Early Childhood Research Quarterly 26(1): 118-136.

Turner T (2010) The jobs immigrants do: issues of displacement and marginalisation in the Irish labour market. Work, Employment and Society 24(2): 318-336.

Vlasblom JD, Schippers J (2006) Changing dynamics in female employment around childbirth. Evidence from Germany, the Netherlands and the UK. Work, Employment and Society 20(2): 329-347.

Wheelock J, Jones K (2002) Grandparents are the next best thing: informal child care for working parents in urban Britain. Journal of Social Policy 31(3): 441-464.

White A (2011) Polish Families and Migration since EU Accession. Bristol: The Policy Press. 
Figure 1: Employment pathways of Irish and Accession state mothers

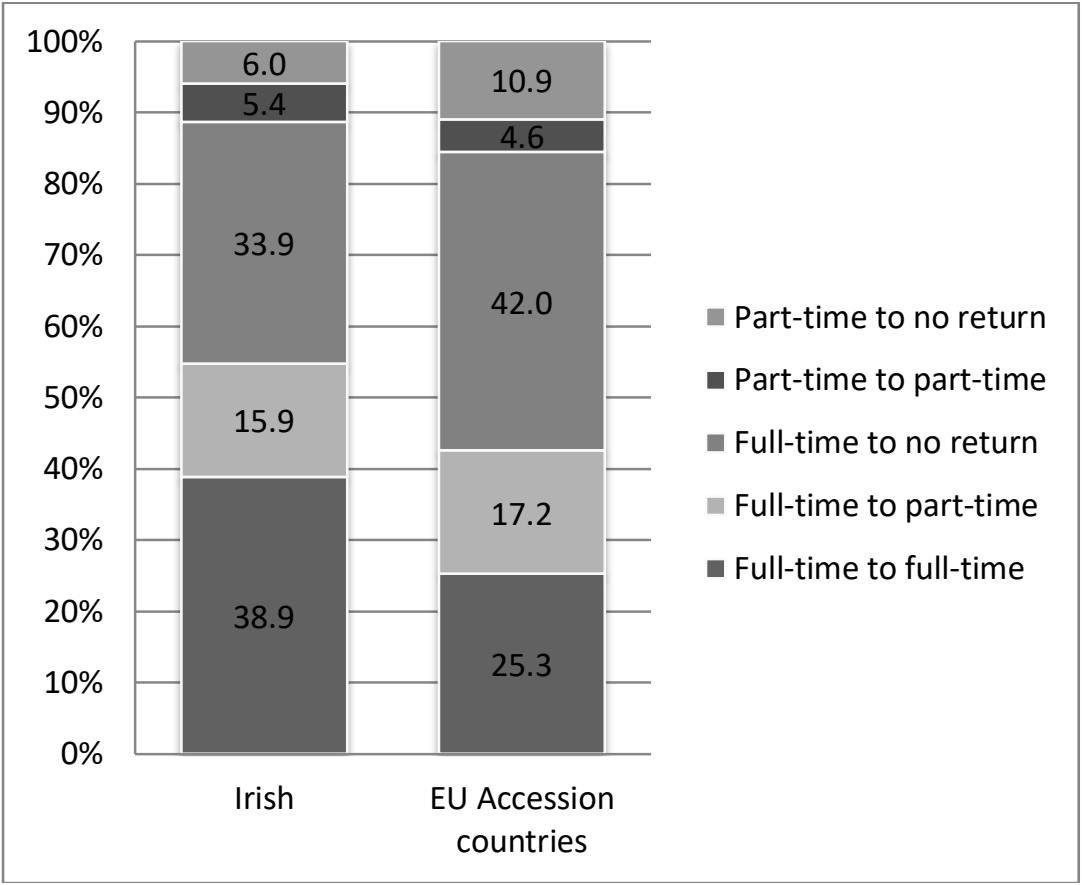

Note: A negligibly small number have increased their work from part-time to full-time hours in both groups and are not included here. 
Figure 2: Work/childcare typologies at 9-months

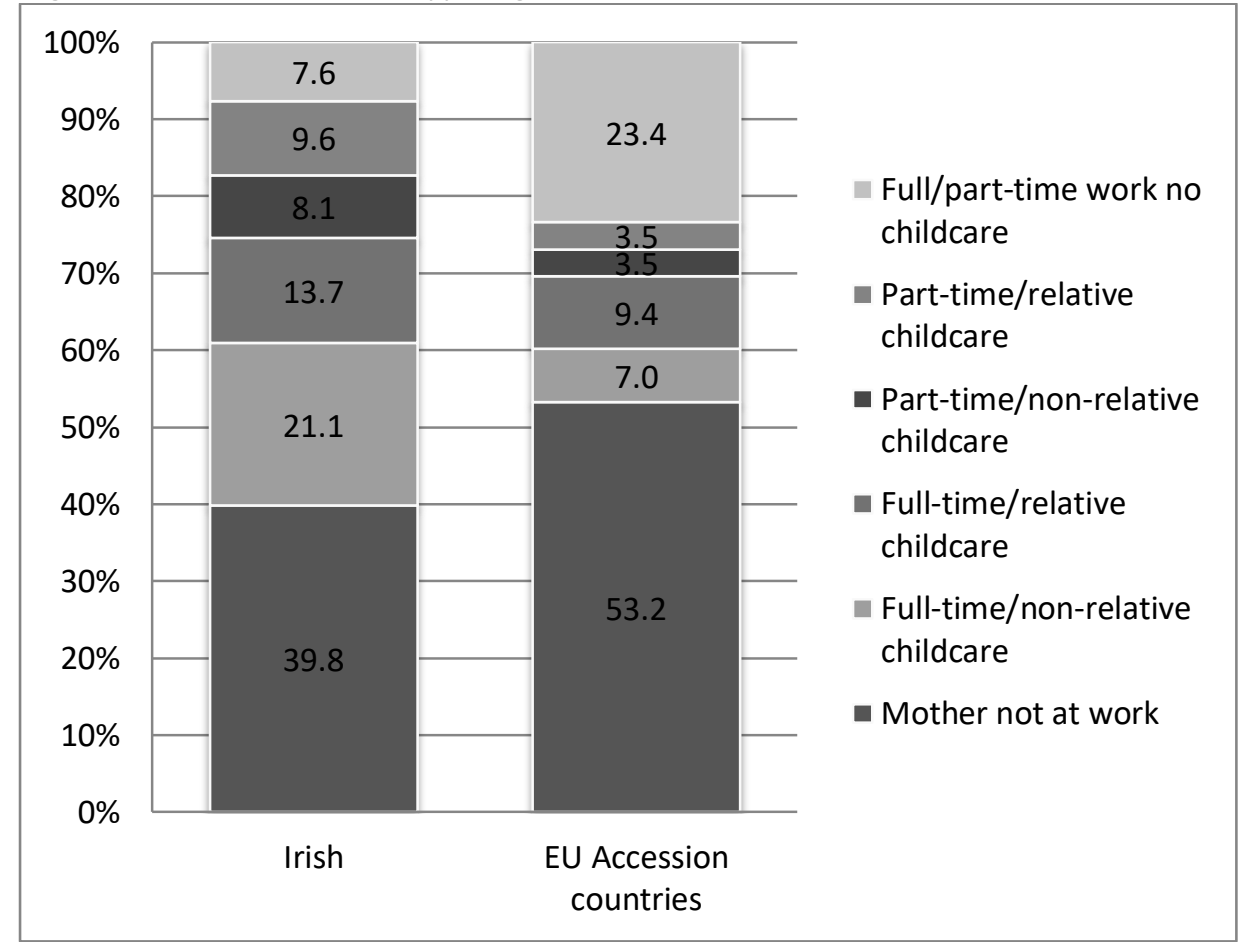


Table 1: Multinomial Regression Models: Work/childcare combinations (Reference category: not working and no use of non-parental childcare)

\begin{tabular}{|c|c|c|c|c|c|}
\hline & $\begin{array}{c}\mathrm{FT} / \text { non- } \\
\text { relative } \\
\text { childcare } \\
B(S . E .)\end{array}$ & $\begin{array}{c}\mathrm{FT} / \text { relative } \\
\text { childcare } \\
B(S . E .)\end{array}$ & $\begin{array}{c}\text { PT /non- } \\
\text { relative } \\
\text { childcare } \\
B(S . E .)\end{array}$ & $\begin{array}{c}\text { PT/ elative } \\
\text { childcare } \\
B \text { (S.E.) }\end{array}$ & $\begin{array}{c}\text { FT or PT, no } \\
\text { childcare } \\
B(S . E .)\end{array}$ \\
\hline \multicolumn{6}{|c|}{ Model 1} \\
\hline EU Accession & $\begin{array}{l}-1.394^{* * *} \\
(0.180)\end{array}$ & $\begin{array}{l}-0.667^{* * *} \\
(0.163) \\
\end{array}$ & $\begin{array}{l}-1.134^{* * *} \\
(0.247)\end{array}$ & $\begin{array}{l}-1.304^{* * *} \\
(0.246)\end{array}$ & $\begin{array}{l}0.831^{* * *} \\
(0.129) \\
\end{array}$ \\
\hline \multicolumn{6}{|l|}{ Model 2} \\
\hline EU Accession & $\begin{array}{l}-1.327^{* * *} \\
(0.203)\end{array}$ & $\begin{array}{l}-0.595^{* * *} \\
(0.184)\end{array}$ & $\begin{array}{l}-1.081^{* * *} \\
(0.278)\end{array}$ & $\begin{array}{l}-1.277^{* * *} \\
(0.282)\end{array}$ & $\begin{array}{l}0.977^{* * *} \\
(0.142)\end{array}$ \\
\hline$>5$ years & $\begin{array}{l}0.105 \\
(0.480)\end{array}$ & $\begin{array}{l}0.213 \\
(0.408)\end{array}$ & $\begin{array}{l}0.113 \\
(0.655)\end{array}$ & $\begin{array}{l}0.432 \\
(0.591)\end{array}$ & $\begin{array}{l}-0.406 \\
(0.342)\end{array}$ \\
\hline \multirow[t]{2}{*}{ Competent English } & $\begin{array}{l}0.620 \\
(0.355)\end{array}$ & $\begin{array}{l}0.561 \\
(0.354)\end{array}$ & $\begin{array}{l}0.284 \\
(0.449)\end{array}$ & $\begin{array}{l}0.557 \\
(0.483)\end{array}$ & $\begin{array}{l}0.622^{*} \\
(0.289)\end{array}$ \\
\hline & \multicolumn{5}{|c|}{ Model 3} \\
\hline EU Accession & $\begin{array}{l}-0.849 * * * \\
(0.223)\end{array}$ & $\begin{array}{l}-0.422 * \\
(0.209)\end{array}$ & $\begin{array}{l}-0.867^{* *} \\
(0.302)\end{array}$ & $\begin{array}{l}-1.167^{* * *} \\
(0.304)\end{array}$ & $\begin{array}{l}0.857^{* * *} \\
(0.179)\end{array}$ \\
\hline$>5$ years & $\begin{array}{l}-0.198 \\
(0.495)\end{array}$ & $\begin{array}{l}0.193 \\
(0.427)\end{array}$ & $\begin{array}{l}-0.069 \\
(0.665)\end{array}$ & $\begin{array}{l}0.597 \\
(0.607)\end{array}$ & $\begin{array}{l}-0.422 \\
(0.369)\end{array}$ \\
\hline Competent English & $\begin{array}{l}0.360 \\
(0.375)\end{array}$ & $\begin{array}{l}0.364 \\
(0.369)\end{array}$ & $\begin{array}{l}0.069 \\
(0.458)\end{array}$ & $\begin{array}{l}0.449 \\
(0.504)\end{array}$ & $\begin{array}{l}0.444 \\
(0.308)\end{array}$ \\
\hline \multicolumn{6}{|c|}{ Mothers' education (Ref: Lower secondary or less) } \\
\hline Leaving certificate & $\begin{array}{l}1.250^{*} \\
(0.493)\end{array}$ & $\begin{array}{l}0.446 \\
(0.298)\end{array}$ & $\begin{array}{l}0.689 \\
(0.512)\end{array}$ & $\begin{array}{l}0.586 \\
(0.309)\end{array}$ & $\begin{array}{l}0.733^{*} \\
(0.351)\end{array}$ \\
\hline Non-Degree & $\begin{array}{l}1.543 * * * \\
(0.479)\end{array}$ & $\begin{array}{l}0.362 \\
(0.287)\end{array}$ & $\begin{array}{l}1.126^{*} \\
(0.487)\end{array}$ & $\begin{array}{l}0.488 \\
(0.301)\end{array}$ & $\begin{array}{l}0.760^{*} \\
(0.341)\end{array}$ \\
\hline Degree or higher & $\begin{array}{l}1.775^{* * * *} \\
(0.480)\end{array}$ & $\begin{array}{l}0.051 \\
(0.296)\end{array}$ & $\begin{array}{l}1.218^{*} \\
(0.493)\end{array}$ & $\begin{array}{l}0.097 \\
(0.322)\end{array}$ & $\begin{array}{l}0.656 \\
(0.350)\end{array}$ \\
\hline \multicolumn{6}{|c|}{ Social class (Ref: Other non-manual/skilled manual) } \\
\hline Prof./managerial & $\begin{array}{l}0.564^{* * *} \\
(0.135)\end{array}$ & $\begin{array}{l}0.290^{*} \\
(0.139)\end{array}$ & $\begin{array}{l}-0.036 \\
(0.175)\end{array}$ & $\begin{array}{l}0.049 \\
(0.166)\end{array}$ & $\begin{array}{l}0.060 \\
(0.158)\end{array}$ \\
\hline Semi-skilled/unskilled & $\begin{array}{l}-0.865^{* *} \\
(0.305)\end{array}$ & $\begin{array}{l}-0.455^{*} \\
(0.231)\end{array}$ & $\begin{array}{l}-0.513 \\
(0.316)\end{array}$ & $\begin{array}{l}-0.406 \\
(0.244)\end{array}$ & $\begin{array}{l}-0.253 \\
(0.213)\end{array}$ \\
\hline \multicolumn{6}{|c|}{ Mother's age (Ref: 26-30) } \\
\hline Under 25 years & $\begin{array}{l}-0.413^{*} \\
(0.208)\end{array}$ & $\begin{array}{l}-0.131 \\
(0.175)\end{array}$ & $\begin{array}{l}-0.428 \\
(0.263)\end{array}$ & $\begin{array}{l}0.246 \\
(0.190)\end{array}$ & $\begin{array}{l}0.008 \\
(0.185)\end{array}$ \\
\hline $31-35$ years & $\begin{array}{l}-0.014 \\
(0.127)\end{array}$ & $\begin{array}{l}-0.627^{* * *} \\
(0.141)\end{array}$ & $\begin{array}{l}-0.051 \\
(0.175)\end{array}$ & $\begin{array}{l}-0.760 * * * \\
(0.182)\end{array}$ & $\begin{array}{l}-0.196 \\
(0.166)\end{array}$ \\
\hline$>35$ years & $\begin{array}{l}0.025 \\
(0.158)\end{array}$ & $\begin{array}{l}-0.842^{* * *} \\
(0.199)\end{array}$ & $\begin{array}{l}0.053 \\
(0.216)\end{array}$ & $\begin{array}{l}-0.697^{* *} \\
(0.240)\end{array}$ & $\begin{array}{l}0.023 \\
(0.209)\end{array}$ \\
\hline \multicolumn{6}{|c|}{ Partner by partner's employment status (Ref: partner working) } \\
\hline Partner not working & $\begin{array}{l}-0.016 \\
(0.256)\end{array}$ & $\begin{array}{l}-0.103 \\
(0.231)\end{array}$ & $\begin{array}{l}0.615^{*} \\
(0.273)\end{array}$ & $\begin{array}{l}0.896 * * * \\
(0.213)\end{array}$ & $\begin{array}{l}-0.298 \\
(0.300)\end{array}$ \\
\hline No partner & $\begin{array}{l}-0.664^{*} \\
(0.262)\end{array}$ & $\begin{array}{l}-1.349 * * * \\
(0.345)\end{array}$ & $\begin{array}{l}-1.175^{*} \\
(0.470)\end{array}$ & $\begin{array}{l}-1.067 \\
(0.388)\end{array}$ & $\begin{array}{l}0.992^{* * *} \\
(0.181)\end{array}$ \\
\hline $\begin{array}{l}\text { No employment } \\
\text { information }\end{array}$ & $\begin{array}{l}-0.266 \\
(0.188)\end{array}$ & $\begin{array}{l}-0.060 \\
(0.191)\end{array}$ & $\begin{array}{l}0.065 \\
(0.235)\end{array}$ & $\begin{array}{l}0.317 \\
(0.215)\end{array}$ & $\begin{array}{l}-0.376 \\
(0.248)\end{array}$ \\
\hline Family nearby & $\begin{array}{l}0.131 \\
(0.107) \\
\end{array}$ & $\begin{array}{l}0.784 * * * \\
(0.133) \\
\end{array}$ & $\begin{array}{l}0.171 \\
(0.150) \\
\end{array}$ & $\begin{array}{l}0.836 * * * \\
(0.170) \\
\end{array}$ & $\begin{array}{l}0.092 \\
(0.134) \\
\end{array}$ \\
\hline
\end{tabular}

$\mathrm{n}=3440 ;{ }^{*} \mathrm{p}<0.05{ }^{* *} \mathrm{p}<0.01 ;{ }^{* * *} \mathrm{p}<0.001$ 


\section{Appendix 1: Attitudes and maternal employment in Ireland and origin countries}

\begin{tabular}{|c|c|c|c|c|c|c|c|}
\hline & \multicolumn{3}{|c|}{ Maternal Employment in \% } & \multicolumn{4}{|c|}{ Attitudes of population (aged $25-35$ years) in $\%$} \\
\hline & \multicolumn{2}{|c|}{ Children $<2$} & \multirow[t]{2}{*}{ Children $<14$} & & & & \\
\hline & $\begin{array}{c}\text { Employed, not } \\
\text { on leave }\end{array}$ & $\begin{array}{c}\text { Employed, } \\
\text { on leave }\end{array}$ & & $\begin{array}{c}\text { Stay-at-home } \\
\text { mother }\end{array}$ & $\begin{array}{c}\text { Mother } \\
\text { part-time }\end{array}$ & $\begin{array}{l}\text { Both full- } \\
\text { time }\end{array}$ & Other \\
\hline Ireland & 45.5 & 12.9 & 56.2 & 27.5 & 45.2 & 14.1 & 13.2 \\
\hline Czech Republic & 9.2 & 9.8 & 59.2 & 59.3 & 25.6 & 10.2 & 4.9 \\
\hline Estonia & 28.8 & $2.2^{*}$ & 64.3 & - & - & - & - \\
\hline Hungary & 11.4 & 1.6 & 53.1 & - & - & - & - \\
\hline Latvia & 34.9 & 21.1 & 68.2 & 62.5 & 25.9 & 7.8 & 3.8 \\
\hline Lithuania & 25.8 & 47.7 & 75.5 & 61.0 & 31.7 & 3.5 & 3.8 \\
\hline Poland & 42.4 & 10.3 & 66.0 & 38.7 & 32.7 & 24.3 & 4.3 \\
\hline Slovakia & 9.5 & 5.7 & 55.7 & 50.7 & 39.5 & 8.9 & 0.9 \\
\hline Slovenia & 56.5 & 18.1 & 81.1 & 13.2 & 38.8 & 42.1 & 5.9 \\
\hline
\end{tabular}

Source: 2012 data from OECD Family Database (2016); ISSP (2012); Cyprus and Malta are not included here, as migrants from these countries are not represented in the GUI data; *in Estonia, a person is considered inactive if on parental instead of maternity leave 


\section{Appendix 2: Descriptive statistics}

\begin{tabular}{|c|c|c|c|c|}
\hline & \multicolumn{2}{|c|}{ Irish } & \multicolumn{2}{|c|}{ EU Accession } \\
\hline & $\mathrm{N}=3199$ & $\%$ & $\mathrm{~N}=636$ & $\%$ \\
\hline \multicolumn{5}{|l|}{ Length of residence } \\
\hline$<5$ years & $n / a$ & $\mathrm{n} / \mathrm{a}$ & 548 & 86.7 \\
\hline$>5$ years & $\mathrm{n} / \mathrm{a}$ & $n / a$ & 84 & 13.3 \\
\hline \multicolumn{5}{|l|}{ English language competency } \\
\hline Not competent & $\mathrm{n} / \mathrm{a}$ & $\mathrm{n} / \mathrm{a}$ & 118 & 18.8 \\
\hline Competent & $\mathrm{n} / \mathrm{a}$ & $\mathrm{n} / \mathrm{a}$ & 511 & 81.2 \\
\hline \multicolumn{5}{|l|}{ Mothers age } \\
\hline$<25$ years & 774 & 24.2 & 224 & 35.2 \\
\hline $26-30$ years & 828 & 25.9 & 289 & 45.4 \\
\hline $31-35$ years & 1,118 & 35.0 & 95 & 14.9 \\
\hline$>35$ years & 479 & 15.0 & 28 & 4.4 \\
\hline \multicolumn{5}{|l|}{ Social class } \\
\hline Professional/managerial & 1,733 & 54.2 & 128 & 20.1 \\
\hline Other non-manual/skilled manual & 871 & 27.2 & 293 & 46.1 \\
\hline Semi-skilled/unskilled & 184 & 5.8 & 147 & 23.1 \\
\hline Unclassified and other & 411 & 12.9 & 68 & 10.7 \\
\hline \multicolumn{5}{|l|}{ Mother's education } \\
\hline Lower secondary or less & 275 & 8.6 & 38 & 6.0 \\
\hline Leaving cert & 593 & 18.5 & 134 & 21.2 \\
\hline Non-degree & 1063 & 33.2 & 223 & 35.2 \\
\hline Degree or higher & 1267 & 39.6 & 238 & 37.6 \\
\hline \multicolumn{5}{|l|}{ Partner by partner's employment status } \\
\hline No partner & 617 & 19.3 & 56 & 8.8 \\
\hline Partner not working & 187 & 5.8 & 102 & 16.0 \\
\hline Partner working & 2120 & 66.3 & 409 & 64.3 \\
\hline No employment information & 275 & 8.6 & 69 & 10.8 \\
\hline \multicolumn{5}{|l|}{ Family living nearby } \\
\hline Yes & 2275 & 71.1 & 205 & 32.7 \\
\hline No & 923 & 28.9 & 422 & 67.3 \\
\hline \multicolumn{5}{|l|}{ Employment status prior to birth } \\
\hline Full-time & 2579 & 80.7 & 441 & 71.7 \\
\hline Part-time & 349 & 10.9 & 84 & 13.7 \\
\hline Not at all & 268 & 8.4 & 90 & 14.2 \\
\hline \multicolumn{5}{|l|}{ Childcare } \\
\hline No non-parental childcare & 1455 & 45.5 & 489 & 76.9 \\
\hline Relative in child's home & 259 & 8.1 & 67 & 10.5 \\
\hline Non-relative in child's home & 63 & 2.0 & 28 & 4.4 \\
\hline Relative in their home & 526 & 16.4 & 14 & 2.2 \\
\hline Non-relative in their home & 389 & 12.2 & 24 & 3.8 \\
\hline Centre-based & 496 & 15.5 & 12 & 1.9 \\
\hline \multicolumn{5}{|c|}{ Main reason for returning to work (out of those working) } \\
\hline Financial/benefits & 1200 & 68.8 & 203 & 80.9 \\
\hline Maintaining career & 375 & 21.5 & 19 & 7.6 \\
\hline Needing an outlet & 170 & 9.7 & 29 & 11.6 \\
\hline \multicolumn{5}{|c|}{ Most important reason for not returning to work (out of those not working) } \\
\hline By choice/preference & 524 & 71.6 & 210 & 73.4 \\
\hline Lack of (suitable) job & 122 & 16.7 & 56 & 19.6 \\
\hline Others & 86 & 11.8 & 20 & 7.0 \\
\hline \multicolumn{5}{|l|}{ Preferred hours (out of those working) } \\
\hline Part-time & 1,792 & 80.1 & 164 & 59.4 \\
\hline Full-time & 444 & 19.9 & 112 & 40.6 \\
\hline
\end{tabular}




\section{Appendix 3: Maternal employment at 3 years of age}

\begin{tabular}{|c|c|c|c|c|c|}
\hline & & Not working & Part-time & Full-time & Total \\
\hline \multirow[t]{2}{*}{ Irish } & $\mathrm{N}$ & 889 & 336 & 1299 & 2524 \\
\hline & $\%$ & $35.2 \%$ & $13.3 \%$ & $51.5 \%$ & $100.0 \%$ \\
\hline \multirow[t]{2}{*}{ Accession States } & $\mathrm{N}$ & 220 & 73 & 161 & 454 \\
\hline & $\%$ & $48.5 \%$ & $16.1 \%$ & $35.5 \%$ & $100.0 \%$ \\
\hline \multirow[t]{2}{*}{ Total } & $\mathrm{N}$ & 1109 & 409 & 1460 & 2978 \\
\hline & $\%$ & $37.2 \%$ & $13.7 \%$ & $49.0 \%$ & $100.0 \%$ \\
\hline
\end{tabular}

Note: there was a substantially higher attrition rate among migrant families (24.5 versus 9.7 per cent) in the second wave. Attrition within the migrant sub-sample did not significantly depend on the characteristics included in the analysis here. 